\title{
THE FUNCTIONS AND SYMBOLISM OF CHINESE MINARETS: A CASE STUDY OF THE HUAISHENG GUANGTA
}

| Received August 29th, 2020 | Accepted November 12th 2020 | Available online December $15^{\text {th }}, 2020$ | DOI http://dx. doi.org/10.18860/jia.v6i2.10209

\section{Hamada Hagras}

Faculty of Archaelogy, Fayoum University

Fayoum, Egypt

hmh00@fayoum.edu.eg

\begin{abstract}
The Huisheng mosque in Guangzhou is one of China's oldest mosques; its initial construction dates back to 627. The minaret of the mosque is one of the surviving earliest examples of Islamic architecture in China. The Chinese minarets were built with a form of a wooden low-rise Chinese pavilion. In the case of Guangta, it was built by brick directly on the street with such a great height. The unique architectural form of Guangta raises many questions about its location, architecture, and function. The study traces the historical texts of the minaret to clarify its historical functions. It attempts to understand the minaret's meanings, the hidden symbolism, and its historical roles to serve the Muslim community as a religious minority in the city, on the one hand, as well as its cultural contributions on the other hand. There are several methods to achieve its objectives: the historical, the descriptive, and the comparative analytical approach. These approaches proved that the minaret played many roles associated with its form and architecture. In addition to its religious functions, it is entrusted to inform Muslims at prayer times. The minaret was also used as a control tower if the Muslim community in the city was exposed to external or internal threats and served as a lighthouse to facilitate Muslim maritime trade. Further, it carried a religious symbolism as it was a symbol of Islam itself within the local Chinese society that was not ruled by Muslims.
\end{abstract}

\section{KEYWORDS:}

Guangzhou, Huaishena, Minaret, Lighthouse, Chinese Muslims, Guangta, Islamic Architecture

\section{INTRODUCTION}

One of the earliest examples of Islamic architecture in China is Guangta "Huaisheng minaret." However, researchers did not examine its functions and roles. The minaret is a testimony to the trade and economic relations between China and the Islamic world. Many studies did not discuss the relationship between the functions of the minaret and its architecture .

Guangzhou city is located in southern China on the Pearl River. It is the Guangdong province's capital city and is the largest city in south China [1]. In the seventh century, The Maritime Silk Road has played an essential role in increasing trade between China and the Islamic countries in the west. The rise of trade between Arabs and the Chinese led many Arabians to visit the city and build the mosque [2]. It is the first mosque in China [3]. This city was distinguished from other Chinese cities by the abundance of Arabs residents [4], which became under their control [2], known as the Arabian Khanfou [4]. The Muslims had an enclave outside the city and was named Fan fang, 蕃坊 [5]. However, Muslims were granted the freedom to practice religious rites and to build mosques.

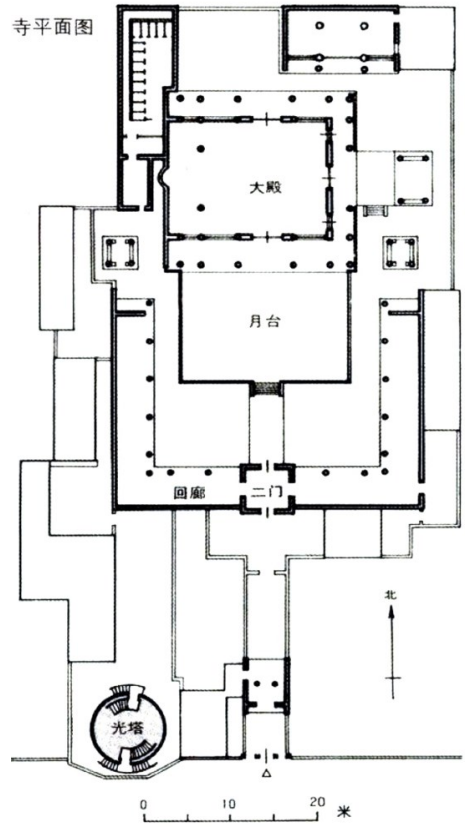

Figure 1: Plan of the Huaisheng Mosque 


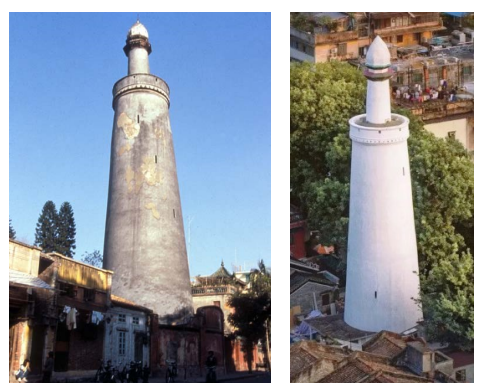

Figure 2: The Guangta Minaret

The Huaisheng Mosque is located in Guangta Road, in the city [6]. It is known as Huaisheng Mosque, 怀圣寺, which means "Remember the Sage-the prophet" [7], as well as Guangta Mosque, 光塔寺, which means "Lighthouse Mosque" [3]. The mosque is the oldest Islamic architecture on the southern coast and all of China [8]. The mosque's initial architecture dates back to 627 during the reign of Tang Emperor Taizong (627-649) [9]. The mosque underwent successive repairs and renovations; it was rebuilt in 1350-1351, during the 10th year of the reign of Yuan Emperor Zhizheng (1341-1370), as well as during The Qing Emperor Kangxi (1662-1722) [8] (figure 1-3).

The Minaret is the oldest architecture of the mosque [10]. It is one of the earliest epitomes of Islamic architecture in China, stands in the southwest of the mosque, overlooks the street, and keeps away from the mosque's gate by 20 meters. It is probably one reason why the minaret is the oldest building in the mosque complex [3]. Unlike the Chinese minarets that have been affected by the pagoda, the Guangta is a straight tapering cylinder [11], which appears to be the influence of the minarets of Central Asia [6]. It was built with grey bricks and covered by a layer of clam [12]. The Minaret has a total height of 36.3 meters [13], divided into two levels; its diameter gradually decreases from the bottom up to 6.7 meters at its upper edge [10]. The upper level is a circular tower that ends with a pointed top [8], based on two layers of Bracket [14]. The study aims to understand the symbolic contents and the many hidden meanings for which the lighthouse was created and keeps track of the minaret's historical texts' structure.

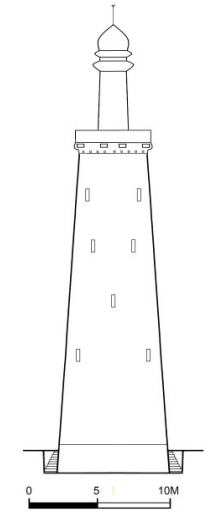

Figure 3: Layout of the Guangta Minaret

\section{METHODS}

The research relies on several methods to achieve its objectives:

- The historical approach, by exposing the historical references that have dealt with the minaret.

- $\quad$ The descriptive approach discovers the Minaret's architectural features and its structure, to which the successive historical texts have referred.

- The comparative analytical approach, by comparing the architecture of the minaret with others in the Islamic world.

- $\quad$ The analytical study presents some hypotheses and ideas about the minaret to reach its contents and tasks, and symbolism for the Muslim community in the city.

\section{DISCUSSION}

\section{FUNCTIONS AND SYMBOLISM OF THE GUANGTA FUNCTIONS OF THE GUANGTA}

Many archaeologists discussed the symbolism of the minaret like Gottheil [15], Cragg [16], and Bloom [17][18]. Hillenbrand notes that the term "minaret" has been applied through a familiar process of semantic neglect to signs, boundary stones, and watch-towers even when no specific association with fire or light was intended [19]. Most of the Islamic architecture in China was not built by the state as was common in the Muslim world, but rather the source of its expenditures came from donations of wealthy Muslims themselves, such as clerics, soldiers, leaders, scholars, merchants, and other; so the financing and expenses of mosques and their economy depended on individual donations. Logically, the frugality in construction had something to consider [20].

Except for the minaret of Guangta, minarets in mainland China always built on the central axis of the mosque, on the same axis as the prayer hall; it is usually centered in the main courtyard of the mosque in the opposite of the prayer hall, also built of wood and rarely exceeded three stories. The minaret's essential functions are giving the call to prayers and visual guidance to the mosque's location. However, these two functions were not presented and not applicable to Chinese minarets. Placed as they are opposite the prayer hall in the mosque's main courtyard, the muezzin's voice could not go as far as needed, and their low height, not exceed ten meters, makes them invisible from outside the mosque [21]. The Chinese mosque lacks the proud and soaring minaret, an indispensable feature of mosques in the Islamic world. Instead, a lowrise Chinese pavilion is assigned to the building. In the case of Guangta, it was built on the street's edge with such a great height.

In one of the mosque's corner, the location of Guangta on the street, far from the prayer hall and its 
unique architectural form, contrasting with all other Chinese minarets, raises many questions. Here we ask a logical question; why was Guangta built with these unique features?

As a religious minority, we believe that Muslims provide the Guangta with many functions and hidden meanings and used it for many purposes; one result was its unique architectural form of Chinese minarets, unique to this minaret.

\section{THE RELIGIOUS FUNCTIONS}

The functions of the minaret are in contrast to the pagodas [22]. The earliest mosques in Islam lacked minarets, and the roof is the earliest method to perform the call to prayer [17]. Adhan was performed from smaller tower structures, which the muezzin gives the call to prayer. The minaret of the Great Mosque of Kairouan in Tunisia is the oldest surviving minaret $\left(8^{\text {th }}-9^{\text {th }}\right.$ centuries) [23]. Some believe that the minaret of Qasr al-Hayr al-Sharqi (730) is the oldest example in the Islamic world [24]. However, the Chinese minarets performed their main function, which is to invite the masses of worshipers to pray in the mosques. Some historical texts have confirmed to us this meaning; Ibn Battuta (d. 1377) tells about Muslims in the city of Khansa-Hangzhou, in which he reported that "their city is good and their markets are ranked as arranged in the Countries of Islam, and there are mosques and muezzins. When we entered the city, we heard the muezzin calling Muslims for Dhuhr prayer" [25]. We can conclude from the words of Ibn Battuta that the Mosques have minarets and muezzins.

\section{THE MINARET AS LIGHTHOUSE}

Ibn Jubayr (1145-1217), The Arab geographer and traveler, indicates the importance of lighthouses. When traveled to Alexandria, he said, "the lighthouse of Alexandria guided the passengers and us to the city, we can see the lighthouse over seventy miles" [26]. AlBalawi ( $d$ 1365) describes the passengers' desperate condition on his voyage to Alexandria because the ship was exposed to a storm until the Alexandria lighthouse appeared. The passengers began to feel safe [27].

However, Trade between the Muslim world and China during the Tang dynasty (618-907) has reached unprecedented proportions. The evidence of these businesses' magnitude is that some researchers have estimated the number of Muslims in Khanfou to be only over 100,000 [28]. We can infer from the historical texts many Muslims in the city during this early time; in 760, during the An Lushan Revolution (755-763AD), many merchants were killed [29]. According to AlSerafi (10th century), another revolution occurred in the year $264 \mathrm{AH}(878-879)$, and the rebels were able to seize Khanfou city and killed one hundred and twenty thousand merchants of Muslims, Jews, Christians, and Magis [30]. The successive events that led to the deaths of tens of thousands of Muslim merchants in the city seem to have prompted Muslims to construct the minaret to monitor their outer perimeter to avoid the risk or similar actions if the Chinese government failed to do so.

The Minaret means the road's guide, light, the sign, and the place used to call the prayer [31]. However, Muslim merchants in Khanfou used the minaret as a lighthouse for commercial purposes and ships' guidance at sea, so the minaret was known as Guangta, the Tower of Light [32]. The minaret location near the seashore and the Pearl River served the commercial business [33], where there was a navigational marker at the top of the minaret. In contrast, the golden phoenix served as a tool for measuring the wind's direction [34].

There are many historical shreds of evidence indicating the function of the Guangta as a lighthouse. In 1088, during the third year of Yuanyue (1086-1094), in the reign of Northern Song Emperor Zhezong (10851100 ), was the oldest textual reference of the minaret, and is the first historical text on the description of the minaret by the Song Poet Guo Xiangzheng (1035-1113). He described the minaret and its functions in his book Qingshanji as follows: "The unique tower raises many questions. It stands like a great pillar and extends upward to the sky. It is located in Wuyue (the foreigner, Muslims), rises sharply from the ground level. It has a way up to the top. It contributes to Fan people's religious rituals [the foreigners], they pray to God to ask for Western winds. The sound of its huge bell is loud and clear. The gray tower in Fanfang, foreigners' settlement (蕃坊) is like the big pen extending to the sky. The sounds of huge drums are blending with bells, which guiding boats and ships on the journey back to the city" [5].

In Tingshi, "Pillar Histories," book of The Song historian Yue Ke (1183-1243), gave us a valued description of the minaret as follow: "On the backside there is the "Stuba" [The Minaret], going high up to the sky, this form of towers is not comparable with any other, the tower is cylindrical and built-in bricks laying up from the base, the outer façade is gray plastered, its shape looks like a silver pen. It has an entrance at the lower level leading up. Spiral stairs are turning every ten steps without being seen outside. In the fourth or fifth month of each year, when the vessels are about to come, the foreign merchants' crowd enters the tower to pray for the southern wind, which always has an answer. The summit is topped by the big golden rooster (金雞) to measure the southern wind's direction. Today one foot [of the golden rooster] has gone missing, which was destroyed and exterminated in the past times" [35].

In 1206, the Southern Song historian Fang Xinru (1177-1222) recorded the minaret's description in his book of Nanhai Baiyong, 100 poems in the South China Sea. He said, "The Tower of Fan [Foreigner people] was built during the Tang period, called Huaisheng Tower. It is a cylinder stands in straightness; its height is six hundred and fifteen Zhang, the tower cannot be compared to others. Its top contains the golden rooster turning with the northern and southern winds. 
In the fifth and sixth months of every year, the Barbarians [Foreign merchants] climb to the top and usually took five drums praying to Buddha [God] for Monsoons" [36].

In 1875, the Anglican priest John Gray (18281890) recorded his visit of the city, quoting from what he mentioned "Upon the minaret, there was, at one time, a gold vane, which in form resembled a gamecock. This vane was broken during a typhoon, which, in the seventh month of the twenty-fifth year of the reign of T'ai-tsu, or Hung-wu, that is, 1393, prevailed throughout the city of Canton, and its environs" [37].

The American missionary Samuel Wells Williams (1812-1884) recorded the minaret "it was built by foreigners, who used to go the top during the fifth and sixth moons at dawn and pray to a golden weathercock there, crying out in a loud voice" [38].

The minaret's questions to the Song historians and poets resulted from its strange and foreign architecture were different from local architecture. According to the Song historian Chao Ju-Kua (Zhao Rukuo) (1170-1231) in his book Zhu Fan Zhi, (諸蕃志), quoting from him "the dwellings of Khanfou were primarily built on wood and covered by straw [39]; as a logical consequence, the city was exposed to numerous major fires in 748" [40]. It prompted the rulers to issue orders to the people in 806 to make their roofs of tiles or pottery [4]. The Huaisheng minaret was built with stone and bricks instead of traditional and local Chinese architecture that relies mainly on timber. It seems that Muslims preferred the stone as a building material to avoid disruption of the minaret functions and the purpose for which it was built.

What reinforces the theory that the minaret served as a lighthouse for commercial maritime routes; The Arab countries had known lighthouses before Islam such as the lighthouse of Alexandria 280-247 BC, which was completely destroyed in 1323 [41]. As was alUbulla in Iraq when the Muslim armies arrived in $12 \mathrm{AH}$ 633 had high lighthouse to guide the ships at night [42]; al-Ubulla was the destination the ships from Oman, Bahrain, Persia, India, and China [43]. Some of Iran's minarets located along main roads or on the edge of the desert played the same role; since many caravan travels were at night, the lamp above the minaret would allow the building to serve as a landlocked lighthouse [44]. The practice of placing a lamp at the minaret top was sufficiently common in Khorasan in 1185 [44].

It appears that the wind vane was aimed at facilitating trade and organizing ships coming to the Pearl River before entering the port. On the other hand, it was used to determine the wind's direction as a guide for sailors. Wind vane was familiar in ancient civilizations; The oldest textual reference to weathercock dates back to $139 \mathrm{BC}$, in The Writings of the Huainan, Huainanzi (淮南子), which describes a "wind-observing fan" (侯風扇) [45]; according to Needham, this vane was a column that ends with a piece of textile. By the 3rd century, the Chinese weather vanes were shaped like birds [32]. As well as The Athens Winds Tower was founded in 50 BC. [46]. In addition, Arab civilization had similar examples; Madīnat as-Salām (Baghdad), which was built by the Abbasid Caliph al-Mansur in 762 -766 , contained a similar wind vane; The historian alKhatib al-Baghdadi (d. 1071) recorded about it, quoting from his record that each of these doors' towers has a divan with a degree on the wall from which it rises. On this divan, there is an excellent adorned dome that goes in the sky. It's thick is fifty cubits, at the top of each dome is a statue run by the wind, not resemble its counterparts" [47].

\section{THE MINARET AS THE VISUAL GUIDANCE}

Ibn Sahib Al Salah (12th century) mentions about the minaret of the Great Mosque of Seville (Giralda Tower) "No minaret rivaled it in all the mosques of al- Andalus... observed from a distance, it would appear that all the stars of the Zodiac had stopped in the heart of Seville" [48]. The minaret is one of the most important elements of the visual formation of Islamic communities. The minarets' visual cue contributed to strangers' guidance to the place where the mosque is located inside the city. The minaret served as a sign to the strangers that the minaret is placed in the Islamic region and distinguished mosques from the surrounding architecture.

A Dutch embassy from the East India Company arrived in Canton in 1655; Johan Nieuhoff (1618-1672) was a member of the Dutch delegation [49]; draw a map and painting to the city (figure 4, 4-a). In his painting, both the Guangta minaret and The Flower Pagoda were the city's highest buildings (figure $5,5-a$ ). It is the function that was the guangta used as a visual cue or guidance.

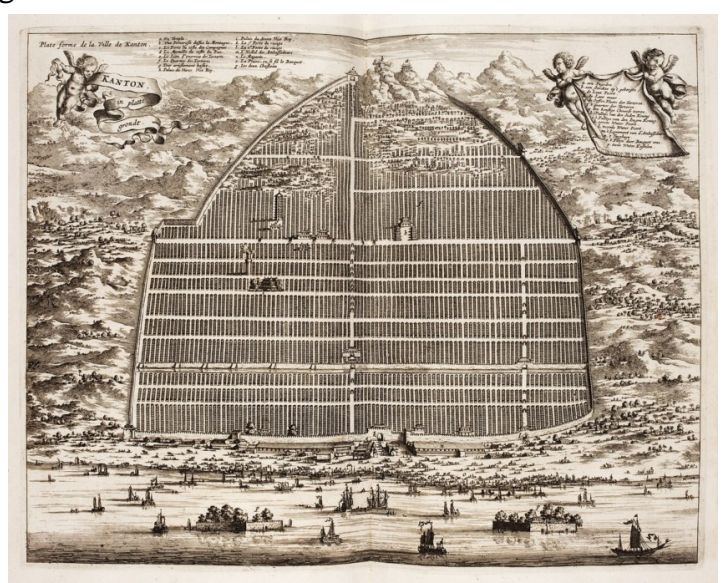

Figure 4: Map of Canton (1655) by Nieuhof. (Nieuhof, 40-41) 


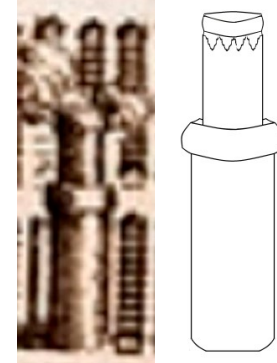

Figure 4-a: The Guangta Minaret of Nieuhof's Map

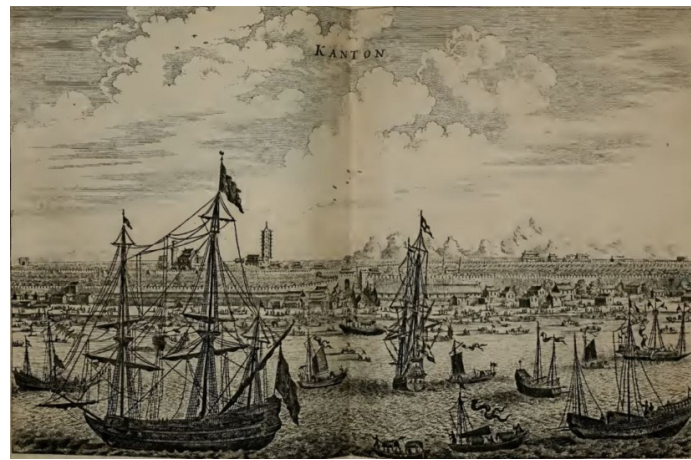

Figure 5: Painting of Canton by Nieuhof

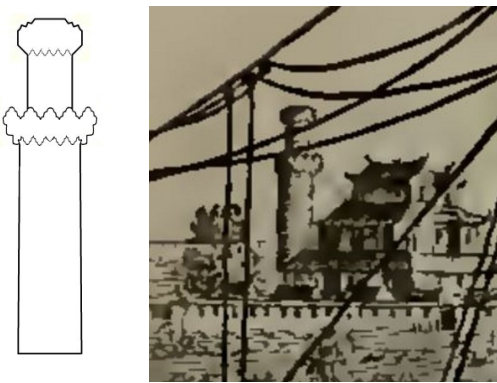

Figure 5-a: Guangta in Nieuhof's painting

\section{THE MINARET AS THE MOON OBSERVATION TOWER}

The moon observation tower is known as wangyuelou [8]. It is used for observing the crescent, hilal. Each month of the Islamic calendar begins at the birth of the new lunar cycle. It depends on the crescent's actual observation on the end of the previous lunar cycle, and thus the last month, and thus the beginning of the new month. Determining the beginning and end of the Arab months is extremely important, as it is related to Islamic rituals, such as fasting, Hajj, festivals, and others. The Chinese historical texts preserved the names of some Muslim astronomers who participated in the scientific renaissance in China during the Song Dynasty, such as the astronomer Moez, , معز(d. 395 AH / 1005 AD), who emigrated from the Arab countries to China in $961 A D$, during the second year of Emperor Jian Long (960963). He also participated in improving Chinese astronomy [50]; Jamal al-Din al-Bukhari, جمال الدين who was a Persian astronomer, also emerged in the records of Yuan [51].

The moon observation tower is common in many Chinese mosques, such as Beijing, Ningxia, and Zhejiang Mosques [52]. Except for the Guangta, the moon observation towers in the mainland China mosques followed the timber frames architecture. They were a low-rise Chinese pavilion, while the Guangta was built by brick and stones, and its height exceeded a few dozen meters. All of this leads us to believe that Guangta was used as a moon observation tower.

\section{THE MINARET AS CONTROL TOWER}

During times of unrest and war, the minarets used as watch-towers or means of communication, such as minarets of Egypt [53]. The minarets of Persia were used for the same purpose [54]. The Guangta acts as an observer tower to explore the general atmosphere surrounding the Muslim community in the city to avoid the possibility of sedition or revolutions affecting them.

Xiangzheng (1035-1113) emphasized the role of the minaret as a watch-tower, quoting from what he said: "It is located in the center of the people of Wuyue [the foreigners]. It is the guard of the three cities, which covers the sky of its surrounded places. Its huge bell sounds are loud and clear and have a protection duty like a tall guard. The sound of huge drum blends with bells" [5]. In the event of disturbances, the minaret was used to warn the Muslim community, through directly struck the drums and bells at the top of the minaret. The Muslim community used it to control the areas and territories surrounding the Islamic city to protect the Muslim community from any dangers, rebellions, etc. In other words, it was monitoring what surrounded Muslims, and if there were a danger, the minaret would help Muslims to take precautions early.

\section{SYMBOLISM OF THE GUANGTA}

The minaret was erected for the sole purpose of informing the time of prayer through the adhan. There were other roles for it, which were not an end and aim in themselves, but were arranged as a direct result of the spread of minarets in the Muslim world from east to west [55]. Minaret serves multiple purposes; it provides a visual focal point and generally invites Muslims to pray (adhan). In early mosques, minarets were erected opposite the qibla wall to be near the Muslim settlements to reach the community for the call to prayer. In Chinese mosques, most minarets were built in the mosques' interior spaces, often in the courtyard of the prayer hall. In contrast, the Guangta minaret was built independently of the site of the mosque. It is located directly in the north-west corner of the mosque on the street; this feature leads us to emphasize that the Guangta minaret had additional roles and functions alongside its religious functions.

\section{THE MINARET AS A SYMBOLE OF ISLAM}

During the Tang period (618-907), The Muslims had an enclave outside the city and was named Fan 
fang, 蕃坊 [5]. However, Muslims were granted the freedom to practice religious rites and to build mosques. The Tang court appointed a judge for Muslims in each city. According to Al-Serafi (10th-century), "in Khanfou, there is a Muslim man. The King of China appointed him to rule among the Muslims going to that area as a vice-king of China. If the feast prayed Muslims, in the Khutbah Commends the Muslim Sultan" [30]. Ibn Battuta recorded about the Muslim community in the city "in some parts of this city, there is the Muslims enclave that has the mosque, the Zawiya, and the market. They have a judge and Sheikh, and must in every country of China, there is the Sheikh, all things of Muslims back to him, and to judge between them" [25].

We conclude from these historical texts that Muslims in city tried very hard to preserve their religious identity and culture in a society that does not follow their religion. They maintained their connection to Islam's lands and the traditional pray for the Sultan of Islam, khalifa, in Baghdad. The tang court seems to have given them the freedom to perform their rituals and practice their law, the most important of which is appointed as a judge to rule among them. In contrast to the Manichaeism that was subjected to restrictions and sieges, in $732 \mathrm{AD}$, a decree was issued described the Manichaean as a heretical group that has nothing to do with Buddhism and is misleading people, so it must be strictly suppressed. So long as the newcomer religion, Islam, did not threaten the Tang family's feudal policy and did not interfere with its policies, the spread of Islam was inevitable [8]. Tang's policy of religious tolerance contributed to Islam's growth, which was accompanied by the Islamic architecture in China. Although Chinese Muslims did not adopt a policy of advocacy to convert to Islam, their architecture and arts were a clear symbol of their culture and a subtle call to be received by the local Chinese until the era of the Mongols.

Islamic art and architecture in China were a perfect example and the most reliable way to express their religious identity and culture to be presented to the local Chinese. It supports our belief is that both the Ming and Qing, pursued the policy of sinicization, the integration of minorities, especially Muslims, into local Chinese culture. Emperor Zhu Yuanzhang-Hong Wu (1368-1398), the Ming dynasty founder, issued a proclamation by which foreign languages, clothes, and names were prohibited [56]. It was an important step to absorb Muslims forcibly. As a result, they lost their independent status [56] [57]. The Ming-Qing period was an assimilation stage of Muslims and erasing everything foreign. During the phase, as mentioned above, the Muslims abandoned their culture. The architecture was one of the fields of this cultural transformation; the brick domes of mosques in mainland China erected during the Yuan era were covered with traditional Chinese wooden ceilings that have been added above those domes during the Ming and Qing dynasties [52]. In other words, they make the brick domes invisible from outside the mosque, such as mosques of Beijing, Hangzhou, and Shanghai.

Furthermore, the Chinese mosques built according to traditional courtyards layout, minarets occupied the mosque's interior, which did not exist on the facade and did not exceed three stories, ten meters. The muezzin takes place in the courtyard to perform the ritual. In addition to emphasizing the Muslim's economic and financial capacity, perhaps the minaret's purpose was to be a symbol of Islam. This tool would promote their status, publicize Islam, and a propaganda tool to attract new followers. Minarets are the most influential element in giving any society the Islamization [55]; many minarets were a factor in providing cities new names like Cairo, formerly known as the city of a thousand minarets. However, the minaret is one of the most important architectural elements of the Islamic city. Still, we can confirm that it became a symbol of it and gradually expanded its symbolism until it became a symbol of Islam. In this context, the demolition of minarets was a desire to erase Islamization; in the countries where Islamic rule ended, Islamic architecture, especially the minarets, was subjected to total demolition such as Andalusia, Balkans, Greece, and other countries [55].

\section{THE MINARET AS SYMBOLE OF POWER}

Another role of the minaret is that it expresses piety and faith [55] and symbolizes power and wealth [58]. The tower had always effectively 'signified the power of the individuals or the institutions that inhabited it or controlled it; The minaret of Jam ( $12^{\text {th }}$ century) in Ghor of Afghanistan [59], was built to commemorate the victory of Ghaznavids. This victory allowed Islam to spread to the Indian subcontinent [60]. Moreover, the Qutb Minar (1192), the minaret of the Quwwat al-Islam (Might of Islam) Mosque in Delhi, which was built by Qutb al-Din Aibak (the viceroy of Muhammad Ghori), with a diameter of $14 \mathrm{~m}$ [61], was a potent symbol of the Muslim conquest of northern India, also marked the beginning of Muslim rule in India. It is considered one of the most important "victory towers" in the Islamic world [62]. Alauddin Khalji (1296-1316) also started building his minaret. The Alai Minar, on the same style as the Qutb Minar, abandoned its construction just after the completion of the first-story core. However, with a huge diameter of 40 meters [55], the Alai Minar built emphasizes the same meaning, might of Islam.

It seems that the minaret of Guangta accompanied the same meaning. Some historical evidences confirms the power of the Muslim traders in Khanfoua during the Tang era. They had become so numerous in $141 / 758$ that they could sack and burn the city and make off to sea with their loot. The same thing was happened in $264 / 878$ [39]. It seems to be due to the port's tax and customs officials [4].

Moreover, the Guangta symbolized a new wealthy class that migrated to China; through their trade. They made a lot of money, which was sufficient to justify their permanent presence in Chinese coastal cities. We give an example here, but not exclusively, 
the history of a Muslim family, the Pu Shou-Geng (蒲壽

庚) family, which has taken the lead in political and economic classes. The Pu family was the wealthiest in China; Pu (蒲) was appointed as the head man of the foreign quarter in the city [57] and was the richest man in the entire region. The family was removed to Quanzhou [63]. The Song court pointed him as the maritime trade supervisor in the Quanzhou port in 1274 [64]

Muslims' strength and wealth are evidenced by what happened between 1068-1077 when Arab merchants donated to repair and renovate Khanfou during the northern Song dynasty. The song court also relied on Muslims' donations in Quanzhou in 1211 during the reign of Emperor Ning Zong (1194-1224) [8]. Anyway, this symbolism of power was associated with the minaret and shared by other architectural elements in mosques, such as domes. Nizam al-Mulk erected such a high dome chamber in Isfahan Jami Mosque (11th century) [65], quite possibly the largest one in the Islamic world at that time. It would assuredly have attracted a lot of attention, not only because of its size but because of its location; it was erected directly through the Sanctuary. That combination of size and site said much about the power of the state. It made the dome an emblem of their authority, visible to all in the mosque [66]. This architectural addition was a prologue to signify the new dynasty's strength and independence, the Seljuqs.

\section{CONCLUSION}

The study examines the historical texts of the Guangta minaret; the Chinese texts recorded by Guo Xiangzheng (1035-1113) in his book Qingshanji, The Song historian Yue Ke (1183-1243) in his book Tingshi, and the historian Fang Xinru (1177-1222); in his book Nanhai Baiyong. As well as the western records by John Gray (1828-1890) in his book walks in the city of Canton, which was published in 1875 , and Samuel Wells Williams (1812-1884) in his book, the Chinese Repository, which was published in 1852 .

The minaret played many roles associated with its form and architecture. In addition to its religious functions, it is entrusted to inform Muslims at prayer times. The minaret was also used as a control tower if the Muslim community in the city was exposed to external or internal threats and served as a lighthouse to facilitate Muslim maritime trade. Further, it carried a religious symbolism as it was a symbol of Islam itself within the local Chinese society that was not ruled by Muslims.

The study demonstrated the minaret's use as a lighthouse to guide ships in the Pearl River and rely on it to determine the direction of the wind through the wind vane, which was erected on its top. Muslim merchants were ascending to the top of the lighthouse, one of the tallest towers in the city to receive incoming ships. Using drums, they were announcing the arrival of commercial marine convoys to the city.

The study clarified the continuous interaction and negotiation of different strands of influence of the Guangta within the peculiarities of time and space. Besides the predominantly religious and economic roles of Guangta, the study confirmed that the Guangta also performed essential functions. The minaret as visual guidance helped strangers to the place where the mosque is located inside the city and act as an important marker signifying the Muslims' presence within the neighborhoods. Its role was to facilitate and regulate trade in the Pearl River and control the areas and territories surrounding the Islamic city to protect the Muslim community from any dangers, rebellions, etc. In other words, it was monitoring what surrounded Muslims, and if there were a danger, the minaret would help Muslims to take precautions early.

The study proved that the case of Guangta and its Islamic architecture form reflected on the interrelations among culture, Islamic identity in a non-Muslim country they immigrated to China and lived in own town in the city, In other words, nostalgia for the homeland, the Islamic world, was born to Muslims, and maintained their culture and languages, in addition, they appeared strong resistance to the policy of the sinicization.

Guangta and its Islamic architecture form also displayed the strong presence of Muslims in the city. Unlike the traditional Chinese towers where timber was the material to build; the Guangta was built by brick and stone. This unique and exotic architecture has raised many questions among travelers, poets, and historians who visited the city. In any case, its construction reflected a measure of the Muslim class's economic potential not only in the city but also in other regions of China, which made Muslims in the second class and lead the political scene later during the Mongol era.

\section{REFERENCES}

[1] X. Guang, Jughrafiat Alsiyn. Beijing: Beijing Foreign Languages Press, 1987.

[2] C. P. Fitzgerald, Flood Tide in China. London: The Cresset Press, 1958.

[3] N. Steinhardt, "China's Earliest Mosques", Journal of The Society of Architectural Historians, vol. 67, no .3, pp. 330-361, 2008.

[4] E. Schafer, The Golden Peaches of Samarkand: A Study of T'ang Exotics. California: University of California Press, 1963.

[5] G. Xiangzheng, Gqīngshānjí. Vol 20, Shanghai: Shanghai gǔjí Press, 1987.

[6] Y. Lu, A History of Chinese Science and Technology, Volume 3. Springer, 2014.

74 | Journal of Islamic Architecture, 6 (2) December 2020 
[7] D. Harper, R. Storey, Hong Kong (Hongkong), Steinhardt (Macao) and Guangzhou (Kanton). Lonely Planet, 1999.

[8] L. Zhiping, Zhōngguó yīsīlán jiào jiànzhú. Beijing: Xinlian Press, 2008.

[9] J. Lipman, Familiar strangers: a history of Muslims in Northwest China. Washington: University of Washington Press, 1997.

[10] Q. Yulan, yīsilán jiào jiànzhú: Mùsilín lỉbà qingzhēnsì. China Building Industry Press, 1993.

[11] A. Petersen, Dictionary of Islamic Architecture. London and NY: Routledge, 1996.

[12] B. She, Yīsillán jiào jiànzhú zhī, yīsīlán jiào jiànzhú, mùsīín lìbài qingzhēnsì. Beijing: Zhongguo Jianzhu Gongye Press, 2009.

[13] D. Yi, zhōngguó tōngshi. Hanyu International Culture, 2006.

[14] L. Lang, Táiwān gǔ jiànzhú tújiě shìdiăn. Yanliu Press, 2003.

[15] R. Gottheil, "The Origin and History of the Minaret", Journal of the American Oriental Society, vol. 30, no. 2, pp. 132-154, 1910.

[16] K. Cragg, The Call of the Minaret. Oxford University Press, 1964.

[17] J. Bloom, "Creswell and the Origins of the Minaret", Muqarnas, vol. 8 , pp. 55-58, 1991.

[18] J. Bloom, Minaret: Symbol of Islam. Oxford: Oxford University Press, 1989.

[19] R. Hillenbrand, Islamic Architecture: Form, Function and Meaning, Edinburgh: Edinburgh University Press, 1996.

[20] H. Hagras, "The Ming court as patron of the Chinese Islamic architecture: The case study of the daxuexi mosque in Xi'an", Shedet, vol. 6 , no. 6, pp. 134-158, 2019.

[21] A. Wahby, Islamic Architecture in China, Mosques of Eastern China, Master's Degree, Cairo. The American University in Cairo, School of Humanities and Social Sciences, 2000.

[22] C. Lo, Z. Luo, Ancient pagodas in China. Foreign Languages Press, 1994.

[23] A. Fikri, L'art islamique de Tunisie : la Grande Mosquée de Kairouan. vol. II, éd. Henri Laurens, Paris, 1934
[24] A. Moussa, almadhin fi aleamarat almisriat wa alam al'iislami, vol. 2. Alexandria: Dar Al Wafa, 2014.

[25] I. Battuta, Tuhfat an-Nuzār fī Gharā 'ib al-Amsār wa 'Ajā' ib al-Asfär. Beirut, 1992.

[26] I. Jubayr, rihlat Ibn Jubayr. Beirut: Dar Sadir, 1964.

[27] K. Al-Balawi, tāj al-mafriq fĩ tahliyat 'ulamā' alMashriq, volume 1, ed. Al-Hasan al-Sa'ih.

[28] E. Schedimore, China: The long lived Empire. The Century Company, 1900.

[29] A. Metz, Islamic civilization in the fourth century $\mathrm{AH}$, translated by Abd el-Hadi abu-Reida. Cairo, 1947.

[30] A. Al- Sirrāfï, 'akhbar alsiyn walhind. Abu Dhabi, 1999.

[31] I. Manzūr, Lisān al- 'Arab, vol. 5. Beirut, 1994.

[32] J. Needham; W. Ling, Science and Civilisation in China: Mathematics and the Sciences of the Heavens and the Earth, vol. 3. Cambridge University Press, 1959.

[33] J. Rugg, Exploring Site-specific Art: Issues of Space and Internationalism. London: I.B. Tauris, 2010.

[34] V. Garrett, Heaven is High, the Emperor Far Away: Merchants and Mandarins in Old Canton. Oxford: Oxford University Press, 2002.

[35] Y. Ke, Tïng shi, vol. 11. Zhonghua Press, 1981.

[36] F. Xinru, Nanhai baiyong, Chongshu jicheng chubian, vol. 3123. Shanghai: Shangwu yinshuguan, 1936

[37] J. H. Gray, Walks in the City of Canton. De Souza \& Company, 1875 .

[38] S. W. Williams, The Middle Kingdom: a survey of the geography, government, literature, social life, arts and history of the Chinese empire and its inhabitants, vol. 1. Routledge, 2005.

[39] Y. Al-Sharouni, min turathina albahri: 'akhbar alsiyn walhind li sulayman altaajir wa 'abi zayd alsayrafi (fi alqarn althalith alhijri/ alttasie almiladi). Al-Dar al-Misriya al-Lebnaniah, 2000.

[40] C. Ju-Kua, Chu fan chi, PETEUSBIRG: Printing Office of the Imperial Academy of Sciences, 1911. 
[43] A. Al-Baladhuri, Futūh al-Buldān, vol. 1, ed. R. Mohamed. Beirut: Dar al-Kutub al-Ilmiah, 1991.

[44] M. Šārôn, "Studies in Islamic History and Civilization", In Honour of Professor David Ayalon. Leiden: BRILL, 1986.

[45] G. Zengjian, Ma Fang, zhōngguó gǔdài kēxué jìshù shi gāng: Lihuà juan. Liaoning Education Press, 1996.

[46] J. Noble, D. Price, "The Water Clock in the Tower of the Winds", American Journal of Archaeology, vol 72, issue 4, pp.345-355, 1968.

[47] A. al-Baghdadi, Tārīkh Madīnat al-Salām waakhbār muhạddithīhā wa-dhikr qutțānihā al'ulamā' min ghayr ahlihā wa-wāridīhā, ed. B. Awad. Beirut: Dar al-Gharb al-Islami, 2001.

[48] I. al-Salah, al-Mann bi' l-imāma, ed. Abd el-Hadi al-Tazi, Beirut: Dar al-maghrib al-Islami, 1987.

[49] J. Nieuhof, Legatio batavica magnum Tartarice chamum Sungteium, modernum Since imperatorem; Historiarum narratione, quae legatis in provinciis Quantung, Kiangsi, Nanking, Xantung, Peking, \& Aula Imperatoria ab Anno 1655 annum 1657 obtigerunt, ut \& ardua Sinenfium in bello Tartarico fortuna, Provinciaurn accurata Geographia, urbium delineation, Amstelodami: Jacobum Meursium, 1668.

[50] Z. M. Isa, "Islamic Astronomy in China, Spread and Development", Academic Journal, no. 4, pp. 217-264, 2008.

[51] H. Hua, minzu wenhua yanjiu wenji, Beijing: Zhongyang Minzu University Press, 2006.

[52] H. Hagras, Almasajid al'thrīat al baqiat fĩ madinat beijin mundh alqarn alrrab' alhijrì (al'shir almiladī) wahatay nihayat alqarn althalith 'shr alhijrī (alttas" "shr almīladī) "drasat 'athriat muemariat", (Ph.D. diss), Egypt: University of Fayoum.

[53] H. Nuweiser, aleamarat al'iislamiat fi misr asr al'uyubiayn wa almamalik, Cairo: Zahraa Al Sharq Library, 1996.
[54] G. Zidan, tarikh altamadun al'iislami, vol. 1, Cairo, 2012.

[55] A. Ameen, "Interpretation of the concept of the Universality as a characteristic feature of Islamic civilization: The case of the minarets", Leptis Magna, no. 1, pp. 17-62, 2014.

[56] B. Pillsbury, "Muslim History in China, a 1300 Chronology", Journal of The Institute of Muslim Minority affairs, vol. 3, no. 2, pp. 10-29, 1981.

[57] A. Benite, "Follow The White Camel, Islam in China to $1800 "$ ", The Eastern Islamic World Eleventh to Eighteenth Centuries, vol. 3, pp. 409426, 2010.

[58] T. Marchand, "Reconsidering the role of the mosque minaret in Sanaa", Proceedings of the Seminar for Arabian Studies, the thirty-Second meeting of the Seminar for Arabian Studies held in London, vol. 29, pp. 95-102, 1999.

[59] J. Moline, "the minart of Jam (Afghanistan)", Kunst des Orients, vol. 9, pp. 131-148, 1973/74.

[60] P. W. Ralph, "Ghaznavid and Ghūrid Minarets", Iran, vol. 39, pp. 155-186, 2001.

[61] A. Petersen, Dictionary of Islamic Architecture, translated by Chuijun Qian, Hui He. Routledge, 2002.

[62] R. Nath, History of Sultanate architecture. New Delhi: Abhinav Publications, 1978.

[63] He Qiaoyuan, Min Shu. Jinan: Qilu Press, 1997.

[64] R. Kauz, Aspects of the Maritime Silk Road: From the Persian Gulf to the East China Sea. Harrassowitz Verlag, Weisbaden, 2010.

[65] A. Anisi, Early Islamic Architecture in Iran (6371059). Ph.D. Thesis, The University of Edinburgh, 2007.

[66] R. Hillenbrand, "Architecture and Politics: The North and South Dome Chambers of the Isfahan Jami'", in E. Herzig and S.Stewart (eds), The Age of the Seljuqs, I.B. Tauris, pp. 148-173, 2014. 